\title{
Boost for French universities following student protests
}

Paris. France's embattled government last week conceded to the main demands of striking university students and staff by agreeing to provide the universities with a FFr4-billion (US\$800-million) rescue package and organize a wide national consultation process aimed at producing a government-endorsed white paper (policy document) on the future of French universities.

The new package - the fourth to be proposed in under six weeks by François Bayrou, the minister for higher education - offers 4,000 new staff posts next year, FFr369 million more to pay for running costs in 1996, and an immediate FFr2 billion for renovations needed to help bring university buildings up to minimum safety standards. Bayrou's first proposal, an emergency plan to help the worst-off universities, offered just 400 new posts and FFr160 million.

The climb-down seems to have been prompted by the prospect that protests by the increasingly organized student movement might add momentum to the massive public sector strikes that have paralysed transport and other services throughout France over the past few weeks. The spectre of the student 'revolution' of May 1968 still haunts French politicians.

Bayrou's latest offer follows two months of growing student unrest. This began on 9 November with a strike by students and staff at the University of Rouen, and has since spread to more than 20 universities, leading to the largest student demonstrations in over a decade. The usually discreet Conference of University Vice-Chancellors (CPU) has also been outspoken in its support of demands for more staff and buildings.

The CPU has welcomed Bayrou's proposals - which meet most of its demands with "great satisfaction", describing them as a "strong sign of a recommitment by the state" to the university system. Similarly, the minister's proposal for a wide national consultation process aimed at producing a white paper on the universities, to include a commitment to multiannual funding, has been cautiously welcomed by many observers as an indication that the government may be ready to make higher education a priority.

The dispute stems chiefly from the failure of government investment in the universities to meet demand in recent years. France has spent more than FFr32 billion over the past five years in building more than 1.5 million square metres of new university space under the Université 2000 scheme, an ambitious plan to reconstruct the university system.
But even this huge investment has fallen far short of needs. Student numbers increased by a quarter during the same period, while teaching staff grew only by 15 per cent.

University buildings are also in dire decay, one in ten falling below minimum

\section{IMAGE UNAVAILABLE FOR COPYRIGHT REASONS}

Revolting: students added to pressure for funding increase staff posts and renovate buildings.

safety standards, and classrooms overcrowded, according to a report commissioned last year by François Fillon, the then minister for higher education. The report said that some buildings should be closed, which would further increase overcrowding. Adding to the nightmare of accountants at the education ministry, a study this month estimated the cost of removing asbestos from the 200,000square-metre campus at Jussieu in central Paris at FFr880 million.

On the bright side, pressure on universities is likely to ease as student numbers decrease in line with the fall in the number of births that started around 1974. Similarly, staff retirements should open up many new junior teaching posts.

But Bayrou's fourth plan still falls short of meeting the demands of the coordination nationale, a body created by student groups during the dispute to provide them with a single voice. It has demanded, for example, that the government create 8,000 new posts next year, free FFr4 billion for immediate renovation work, and commit itself to a plan to spend FFr50 billion over five years.

The coordination nationale has rejected the latest proposals as "insufficient", and called for students to both continue the dispute and widen it to include support for the public sector demonstrations scheduled for this week. But the movement has been weakened by in-fighting, leading last week to the breakaway of UNEF-ID, the main moderate left-wing students' union.

Events this week show whether Bayrou's proposals will take the steam out of the students' protests. There is some evidence, such as the end of strikes at several universities, that this may happen. Declan Butler

\section{India plans to recoup investment through satellite services}

New Delhi. The Indian Space Research Organization (ISRO) says that earnings generated over the next seven years by its latest satellite, INSAT-2C, launched successfully last week by Europe's Ariane rocket, are expected to surpass the total investment India has so far made in space.

There is no reason to doubt this optimism. The single objective of INSAT-2C is to make money by supporting the information and telecommunications industries. In contrast, two earlier satellites in the INSAT-2 series had other aims in addition to providing telecommunication services. For example, both carried meteorological payloads intended to take photographs of clouds and thus provide early warning of imminent cyclones.

This payload was dropped from INSAT2C. Instead, the 2.1-tonne spacecraft was packed with 24 transponders in order to achieve maximum returns from each kilogram of payload placed in orbit. Leasing one transponder alone will generate US\$2 million a year. ISRO has already leased 10 such transponders of the planned INSAT2E to the international consortium INTELSAT for US\$100 million. This satellite is due to be launched in 1997.

The main focus of INSAT-2C is to generate revenue by providing new services to India's business community. Three of the transponders operating in the $\mathrm{Ku}$ band (11-14GHz) were introduced for the first time in INSAT-2C to provide direct links between city exchanges and data services using very small antennas no more than $\mathbf{5 0}$ $\mathrm{cm}$ in diameter. The satellite will also meet the communication needs of railways, trucking services and the shipping industry, as well as individuals on the move.

INSAT-2C cost US\$40 million to build and a further US\$75 million to launch. It will also be a major asset for the statecontrolled television service, Doordarshan. According to ISRO, the satellite will allow Indian programmes to be transmitted for the first time to an area extending from north-east Africa to south-east Asia. This broadened audience is expected to generate a substantial income from advertising.

With 12 of the 24 transponders allocated for Doordarshan's television service, ISRO officials say that INSAT-2C will be a major competitor to the recently launched ASIASAT-2, on which Rupert Murdoch's News Corporation International has already leased eight transponders. Doordarshan has been fighting to regain its share of the audience and revenue lost to Murdoch's STAR TV network. It expects to use five channels for its programmes, and to lease out the rest.

K. S. Jayaraman 